\title{
Legal Modernity and Early Amerindian Laws
}

\author{
William E. Conklin
}

\section{Introduction}

Modern states appear to be dissolving. Enormous violence plagues their dissolution. The day-to-day lives of residents are up-rooted. Suffering results. The United Nations published a study in 1994, for example, that since 1900 there had been 19 million peoples killed in civil dislocations in contrast with the $69,229,000$ persons killed in inter-state wars. 1 Much of the intra-state violence was accomplished under the authority of the state. That is, officials, duly appointed by the state, carried out the killing as if their actions were legally authoritative.

State violence occurs in two different contexts. First, newly formed, geographically smaller territories claim recognition as sovereign states. In this circumstance, one state claims an identity with historical origins which separates the state from its 'colonial' master. Secession is the name of the day. The master and seceding state disagree as to who founded the state, when the state was founded, in what context and the freedom of choice of the 'populace' when the state was formed. This first manifestation of state violence has been exhibited in the present countries of Canada, the United Kingdom, Sri Lanke, Belgium, Italy, Spain, Nigeria, and Indonesia and in the former states of the USSR. Yugoslavia, and the Belgian Congo.

State violence has occurred in a second context. Sometimes simultaneously, sometimes as a precursor, sometimes as a postscript to the rise of a modem state, a closely-knit community, bonded from centuries of tribal customs, rejects the very sense of legal authority which is associated with the modern state. Such a phenomenon has recently been exhibited in Canada, Australia, Rwanda and Somalia.

What I wish to suggest is that, on occasion, the violence which has plagued our century has been coloured by the clash of two very different senses of legal authority. The competing senses of legal authority correspond with the two very different contexts of civil violence: the secession of one state from another on the one hand and the appeal to a radically different sense of legal authority on the other. 


\section{Modern Legal Authority as a Quest for a Foundation}

The first sense of legal authority, associated with the modem state, accepts the claim that a foundation or source or originating moment grounds all human laws. Philosophers have described such a moment as an archimedian point, taking the word arche from the Greek sense of foundation. Such an archimedian point is postulated in judicial reasoning as much as it is in the legislative process. Such a quest for a source or foundation. Michel Foucault has argued, began in the early modern era when the sovereign European state was taking its first monarchical form in the 1700's (Foucault. 1991, 1980). Hannah Arendt has claimed that the search for an origins or grounding to human laws began with the Romans and their sense of the rule of law (Arendt. 1961). It is possible to read Plato's Republic and Laws as reflecting a similar association of the rule of law with some founding moment of the state. Even Creon proceeded, at an early moment in Sophocles' Antigone, as if his edict would not be legal unless he proceeded to ground his edict in the consent of the Councillors who represented the state. The key here, however one interprets the historicity of the idea of a source or foundation of legality, is that juridical agents re-present or signify the postulated originating source after the source was present. Human laws are posited after the archimedian point. Language can only reach so far in its representation of the foundation. For the foundation, to be a foundation or ultimate source, must be external to human laws. A presence with the arche is inaccessible from within the language of lawyers, judges, legislators and their agents.

In their act of representation, juridical agents function as surrogates for the originating moment of legal authority. Lawyers and judges, police persons and social workers, state psychiatrists and prison guards enforce human laws in the name of the Law or the Rule of Law or Justice. Juridical officials are agents of the originary archepoint of the legal order. They can never gain a presence with the originary foundation because the foundation pre-exists their historically contingent circumstances both in time and space. The best that juridical agents of the originating grounding can do is to picture the foundation. The picture is drawn cognitively, in the imagination of the agents. Sometimes, as with Thomas Hobbes, the picture is of a natural condition where creatures do not and cannot speak a language. Jean Jacques-Rousseau pictures a universal general will which.transcends all particular wills in a society. On other occasions, as with Ronald Dworkin, the picture is of a "law beyond law" where all rational contradictions have been reconciled. The juridical official must have faith in such a world. Mystical intermediaries - Hercules and Hermes - intercede from on high and carry a cohesive theory of law to the "high priests" - the judges of the Supreme Court - of "law"s empire". On still other occasions, as with Hans Kelsen, the picture projects a pyramid of norms with one single presupposed thought at the pinnacle of the pyramid. Even H.L.A. Hart postulates a concept of law which can only "approximate" a prior "pre-legal" condition before lawyers and judges set to their task of speaking and writing. The impersonality and the finality of humanly constructed laws differentiates a modem from what Hart and Kelsen call a "primitive" legal order. The picture of this external foundation, whatever its boundaries, dominates the lawyer's enterprise in a modern state. The lawyer is "haunted" - Hart's term - by the possibility that there was once upon a time a prior condition before human laws were posited. The picture encloses what the juridical agent can and cannot do. But one must not forget that the picture is produced cognitively, in the imagination of the legal agents of the imagined externality.

Two factors combine in the privileging of the externality of the foundation. For one thing, the trace of laws to an external grounding allows juridical officials to claim that human laws are separate from the personal whims and moral/religious rules of the officials. The Roman jurists played to such an impersonal grounding in order to legislate and to adjudicate over such culturally and linguistically diverse peoples as the Latins, Egyptians, Greeks, Gauls, Anglo-Saxons, Germans and Slavs. The Romans distinguished auctoritas from the potestas and potentia of the ruler. Potestas and potentia went to the effective power of the ruler; auctoritas went to the legitimacy of the ruler's laws. An official's auctoritas depended upon the ruler's role in state institutions rather than upon the ruler's virtues. In contrast with the Greeks, the Roman sense of auctoritas dwelled external to and independent of the ruler's personal virtues. Aucforitas delineated boundaries within which an official might act authoritatively. What Plato described as mere opinion was, for the Romans, authoritative if auctoritas coloured the opinion. If an official acted within authoritative boundaries, his acts were considered intra vires; if outside, they were considered ultra vires. The vires juridified a humanly motivated act. Auctoritas constrained an official from acting beyond delineated boundaries. The auctoritas even constrained the Emperor if he should claim to embody authority.

A second characteristic colours the originating grounding of a modern legal order. The originating grounding is believed to be external to the humanly posited laws. This extemal situs of the ultimate foundation, external in time and space, distinguishes the foundation from historically contingent ordinarily authored laws. The externality of the foundation vis-a-vis ordinarily posited laws is critical. Without such an externality, the foundation would not be a foundation, it would not finalize the posit of human laws. Without a finality, any one statute or judicial decision or executive act would be a transient or fragmentary expression. How could a rule or norm be posited if it were a transient fragment of a text? Any one script would be subject to the scepticism that the script represented a binding law. For how could an object be considered binding if it might continually be changed like the ebb and flow of a river, as Heraclitus described? How could the object of such a script be recognized by a judge, let alone by a citizen, if the ultimate grounding of the fragment continually changed? And how could a rule be considered a general rule if it might exist as a goveming 'rule' one minute and not the next? if it might apply to a person one minute and not the next? if it were not general because of its momentary character? For any script, such as a statute, to be considered authoritative, it must be locateable in a measureable time and 
space. That is, one must be able to locate when and where the script was posited or laid down. That measureable time and space locus depends upon the success of a legal theory to suggest a final grounds or foundation for all humanly posited rules or principles. The consequence of the lack of finality in a series of legal texts is that the script of any one author is a testiment to the particular author's personal will. The impersonality of the Roman sense of auctoritas thereby dissipates into the author's naked imposition of force. More, without finality, how could any one authored rule be considered posited? The rule would be a mere transient moment in the ever changing expressions of institutional sources. Only if one could interpret, act, decide or legislate as if some externally situated foundation authorized the interpretation or action: only then would an impersonality colour any socially contingent rule or norm.

The quest for an originating source or grounding of all legal nules and principles raises important issues concerning the civil violence of a modem state. How is it possible that so much pain may issue from the acts of legal officials in a modem state? Why does the authoritative origins of a stipulated rule elevate the violence of the state above the crass and vulgar action of the gangster? Does the impersonal finality in the otherwise infinite differentiations and fragments of legal language privilege why agents of the modem state may detain, repossess, imprison, torture, and kill human subjects under the colour of authority? Does the finality distinguish the authority of such an agent as compared with that of a poet or novelist? Why is a judge's ruling authoritative in some circumstances and not so authoritative in others? Why does a judge consider an authoritative rule binding whereas a judge will consider a poem or novel or the moral offensiveness of certain acts as irrelevant to the authority of a juridical act? Do lawyers and judges seek out the final end of analytic reasoning rather than the truthfulness or wisdom of statements of non-knowers of the concepts of the reasoning? Or is the final end of reasoning the same first cause as the Truth of an act?

Another set of issues goes to the question, "what institution best represents the final grounding of modem legal authority?'. Does the ultimate grounds rest in the sovereign legislature? Is the legislature subject to the rules of some basic text? Are the doctrines and rules of that text subject to the intent of the Founding Fathers of such a basic text? What grounds the basic text? Put differently, what do the juridical agents consider the grounding of the basic text? What drives juridical agents to desire such a grounding? Indeed, why must there be a foundation or tinal grounding to the posit of a rule? Is the foundation internal to the posited nules? Is the foundation the Head of the legal order? the King or Queen? the Parliament? the Prime Minister? Or is the foundation external to the interrelations of posited rules? If external, is the foundation inaccessible from within the language of posited rules? If so, is there a component of a modern legal order which cannot be attributed to human action? Is there an invisible author, such as the "general will" or rationally cohesive author of Dworkin's stripe, or an ultimate source, as in Kelsen's or Hart's case, hidden behind all juridical acts? Is the foundation of the legal order an a priori concept or thought? Whether an author or an a priori concept, does the foundation lack an object to which it can refer? For how could an author or a concept be a foundation if it still referred to another object? Wouldn't that object be the foundation?

If the foundation lacks a referent, if it is an in itself that is, is the foundation also nameless in that the foundation can only be symbolized rather than signified? That is, can one represent the foundation or arche point of legal authority in language? If the foundation is inaccessible from within a language of posited laws, does that inaccessibility possess a divine quality? If so, what is the character of the constraint towards which the juridical agent feels bound as s/he interprets authored texts? How can a source or grounds constrain a human agent if the source lacks a referent and remains nameless? Do posited rules merely approximate the inaccessible foundation? If so, do the posited rules construct the identity of the foundation, all the while that the foundation remains inaccessible to the agents? Are the agents constrained by the mediation of a ghost-like figure? Is this ghostly source divine in that human agents cannot recognize, picture, imagine, perceive or conceive it except through humanly authored instruments?

The key to these questions, 1 believe, lies in the certain belief in a modem legal order that, at bottom, there is a foundation or arche or originating moment to all juridical acts. If juridical act were merely transient, then there would be little to differentiate it from the personal act of an arbitrary gangster, it is thought. The transient personal act too would be arbitrary. There would be no way to ascertain that a juridically authorized act was "law" except the efficacy of that act. There would be little to colour any act of a state official with impersonality. And there would be little to justify the state's monopoly over authoritatively imposed coercion. The result is that all juridical officials function as surrogates for the originating grounding whose identity is without form or substance until officials begin to give it an identity.

\section{The Laws of Early Amerindian Tribes}

Let me now tum to the tribal laws of Amerindian tribes prior to the invasion of the Europeans. I shall confine myself to the tribes which lived in the territory presently known as Canada.

Prior to the European invasions five hundred years ago, no single Indian language nor single Indian culture inhabited present-day Canada. Yet, despite their differences, the indigenous clans and tribes seemed to share a similar sense of 'what is law?'. The authority of laws shared amongst the indigenous inhabitants of a tribe was bodily, experiential, unwritten, unauthored, and closely identified with nature.

For the tribe, in the furst place, the time and place of the origin of laws was unknown. One could not even trace tribal laws to some foundational source such as we can with a modem state, to some Founding Father or natural disaster or 
transcendent concept or Grundnorm. Tribal laws were deeply rooted in tribal culture so as to generate 'givens' within the tribe. The village and tribal councils did adjudicate disputes between members of different clans within the village. But what the tribal councils considered as 'law' was not legislated or authored by some earlier or superior council (Trigger, 1969, pp. 73-4). Issues were usually discussed until a general consensus was reached. Even the tribal and village councils of the Confederacy of the Hurons, a group of tribes sometimes likened to a state, did not function as authors of the tribal laws. The Confederacy of the Hurons met each spring for several weeks. Their meetings were formal Representatives of each tribe and village were given an opportunity to respond to questions through a language, called acwentonch, which was different from the everyday languages of tribal members. And yet, despite the formalism of procedure and language, the Confederacy was organized about local clan groupings which refused to surrender their "authority" over their intemal affairs to any higher body. The council of the Huron Confederacy could not enforce its decision upon a delinquent clan or clan member. The Council could only recommend. The clan chiefs had to consent to any recommendation of the Huron council. The chiefs, in turn, had to gain the verbal support of particular clan members.

Secondly, tribal laws were not put to writing. This unwritten character of the laws contrasts with the codes and statules of a modem state. Laws were not analyzed as concepts or doctrines. The youth of the Iroquois and Huron did not go to a 'law school' to learn the laws. There were no professional experts. Rather, the tribal members assimilated unwritten laws as young people. They did so through ceremonies, public feasts, dances, lacrosse matches, songs, initiations into the adult tribal community, and the like. With a modern state, texts are very important. But with an Amerindian tribe, a natural object, such as a plant or animal, usually symbolized the legal order. The symbol connoted a religo-magical character (Trigger, 1985, pp. 102-03). The symbol, called a totem, did not represent some concept in a metaphysical structure lying behind the totem. Rather, the clansmen experienced the symbol in their day to day lives. Members of the same torem clan, for example, could not intermarry. Nor could they eat the totem species. Tribal members did not debate whether a law ordered a member to act in a certain manner. Nor did a tribal member even reflect upon the goodness of a practice which s/he took as law. Rather, the tribal member experienced the symbol/totem in her/his day-to-day life. The end of all practices, the symbol, addressed each person's experiences. The symbol spoke to the addressee.

Amongst the lroquois, for example, the death of a member of one's tribe by an outsider might cause a war. The death of one member affected each and all in the tribe because members supported each other physically and socially as they sought out a subsistence living. The unwritten practices of the Iroquois required that a victim's tribe seize a member of the offending tribe in order to compensate for the loss of the victim. Failing compensation, the tribe sought retribution by killing the offending individual, scalp his head as a trophy to the offended tribe (Trigger, 1985, p.97). Precisely because such a practice was so intertwined with the personal experience of having lost a clan member, any one event possessed several interpretations, depending upon which clan and which tribe interpreted the event. And yet, the "sentencing" experience itself was accepted by all as lawful. The unwritten laws were lived. Sophocles' Antigone described just such laws when she exclaimed in her infamous defence in a passage, cited by Aristoule as the authority for natural law thinking, that the "great unwritten, unshakeable traditions" were "alive, not just today or yesterday: they live forever, from the first of time, and no one knows when they first saw the light." (Sophocles, 1962, line 504-08). The tribal member experienced a law through her/his body, not as an object of cognitive reflection.

Thirdly, because the survival of certain tribes was so dependent upon nature, the Amerindian tribes closely associated their unwritten laws with the natural condition. The customs of different tribes varied from one physical locality to the next, depending upon the environmental context where the tribe lived ( $R$ Douglas Francis, 1982, pp. 4-18). The eastem Algonkins did not recognize a distinction between the natural and supernatural, between the body and mind, for example, as did the Jesuit priests who had brought the beginnings of European science with them (Bailey 1969, p.133). Tribal members were preoccupied with surviving the rugged Canadian winter. All signs about the duration and the rigour of a coming winter and the prospect of little or great amount of foods which would result: such signs took on a divine character.

More generally, the environing world of the Amerindians drew superhuman and magical powers from the environmental contexts of subsistence living. These spiritual powers were believed to control one's destiny. Spiritual nules and taboos, for example, surrounded the hunting practices of the Micmacs who occupied present-day Nova Scotia, northern New Brunswick, the Gaspe Peninsula, Prince Edward Island, and Cape Breton Island. (Martin 1991, pp. 193-96). The Micmacs saw themselves as connected with a whole coherent ecosystem where each animal respected the other. Unwritten customs associated with such an ecosystem prohibited excessive hunting. Cusioms regulated the remains of dead anjmals. Rituals surrounded the killing and processing of animal carcasses. What "is" in nature ought to be. There was no distinction between what "is" and what "ought" to be, between posited laws and natural laws. Such a distinction, of course, is fundamental to the legal positivism in a modern legal discourse.

During recent years, particularly in Canada, the laws have been transformed as lawyers and judges have read their own environing world into the customs of the Amerindian claimants and defendants in Canadian courts. Sometimes, especially in the more serious confrontations with the Canadian legal order, such a displacement is exhibited in all its naked violence. This transformation has taken place as lawyers cognitively enclosed the customs of the tribes with the doctrines and categories of a modern legal discourse. The tribal laws have remained unwritten and, therefore, unrecognized in the modem legal discourse. Tribal laws were sometimes not even communicated through the spoken word. Rather, tribal customs were 'known' and lived through the experiential bodies of tribal mem- 
bers. Tribal customs were meant, not represented or signified in a written language. The meant objects of tribal members were addressed from and to tribal members, not from and to a special cadre of expert knowers as is the case in a modern legal discourse. One can appreciate, then, the distancing event which the tribal member experiences as $s / h e$ is tried in the formal procedures and doctrines of a modern European state, such as the Canadian. A rational, written, reflective legal discourse displaces an uncoded, bodily, experiential and authorless sense of law. The formalist and rational metaphysics of a modem state carries a violence to its very core, no matter how impersonal and final the appearance of posited laws.

\section{The Concealment of Amerindian Legal Authority inside a Modern Legal Discourse}

Let me be more specific by referring to the constitutional context of what the United Nations has called, three years in a row, as the most preferred country in which to live on earth. Canadian constitutional discourse, when confronted with claims of indigenous land claims, has presupposed what H.L.A.Hart attributed to an imperative theory of legal authority. (Hart 1994, pp. 18-25). The latter associates legal authority with a hierarchy of juridical officials. At the pinnacle of the hierarchy is situated an historically contingent sovereign author with supreme and unlimited authority to make orders backed by the threat of force. There is much in Canadian constitutional discourse surrounding aboriginal land claims which manifests such an imperative theory. Both statutes and judicial texts presuppose that an ultimate source - the Crown - owns title to all land. The Royal Proclamation of 1763 , for example, stated that ultimate sovereignty rested with the Crown. The Royal Proclamation stated that the aboriginal peoples could retain their lands until the Crown, as the founding author of the juridical structure, ceded the lands to the aboriginal peoples. The Crown reserved land for the Amerindians. The tribes authoritatively possessed land only by virtue of the juridical officials recognized in the modem legal discourse.

One can appreciate how the European legal discourse assimilated the tribal laws into the European discourse when one reads the Proclamation closely. In addition to reinforcing the pyramidal hierarchy of the European legal structure, the Royal Proclamation, in the Indian version of its preamble, considered the tribe as synonymous with the nation. The Proclamation associated a single language with a European nation and yet, the Amerindians had spoken several hundred languages. Shared cultural practices are often considered important in the identification of a nation and yet, each Amerindian tribe identified with a different totem and, most certainly, considered itself as different from the next tribe.

Higher court decisions have deferred to this pyramidal (or sometimes called patriarchal) and imperative sense of legal authority to this day. Although the Canadian Supreme Cour has recognized the legal right of indigenous inhabitants. to possess their lands in Guerin v. The Queen, ${ }^{2}$ for example, such a right of possession has been held subject to the unlimited 'ultimate title' of the King of the state. The original inhabitants may not alienate their land without first conveying the land to the Crown, according to Guerin. The Crown, in tum, may sell the land to a third party if the Crown claims and if the Crown in fact acts on behalf of the original inhabitants. In deferring to such a pyramidal sense of authority, the Guerin Court situated the land claims of the indigenous peoples within a secondary language meant for expert knowers ajone. Such a specialized and scientized language privileged the trace of authority to some transcendental source, the King.

The Canadian courts have immersed an unwritten, bodily, experiential sense of legal authority, shared amongst Amerindians, into the secondary signifying relations of the legal discourse. The secondary discourse differentiated the Amerindian claims from the specialized language which the professional knowers recognized as their own. The professional language concealed the languages of the Amerindians. For example, the judges in Guerin deferred to Chief Justice Marshall of the United States Supreme Court who, in Johnson v. M'Intosh, had recognized that the Head of modem state, not the Amerindians tribes, owned all land ${ }^{3}$ Although the original inhabitants possessed legal claim to possess their land, according to Marshall, C.J., "their rights to complete sovereignty, as independent nations, were necessarily diminished" by virtue of the imperative sense of authority. In Marshall's words, the "original fundamental principle" gave "exclusive tite" or "absolute title" to the invader. Such an "original fundamental principle" also granted the "just claim" of the first inhabitants to possess their land. Possession, yes; title, no. According to the Guerin Court, such an aboriginal claim of possession pre-dated the Royal Proclamation, the Indian Act and all other executive and legislative provisions. That is, the legal discourse of a moden state was held to pre-date the language which the professional knowers now wrote. Such a claim to possession, though, was subordinate to the prior exclusive title in the Crown to own all land.

Why did the language of professional knowers privilege the aboriginal right to possess land prior to the European invasion? Why did such a language privilege the exclusive title of the Crown - the sovereign 'author' of all authoritative writing - to all land in the Crown?

These questions can only be understood in terms of the sense of authority which the British and then Canadian common law courts have taken for granted as a 'given'. The quest for an arche has resulted in the exclusion, ignorance and concealment of the bodily, experiential, unwritten sense of authority shared amongst Amerindian tribes prior to the European invasions. As Lord Watson stated in the Privy Council decision of St Catherine's Milling \& Lumber Co. v. The Queen, ${ }^{4}$ again accepted by the Supreme Court of Canada in Guerin, "there has been all along vested in the Crown a substantial and paramount estate, underlying the Indian title, which became a plenum dominium whenever the title surrendered or otherwise extinguished." The European sense of authority did not and could not 
allow the tribal laws to exist outside the cognitive doctrines and procedures of the modern legal discourse. The signifying relations of the modem state "totally dominated," just as Lord Watson acknowledged had to be the case. Lord Haldane also deferred to the master legal discourse of a modem state and its privileging of a supreme source of all laws in the Head of the pryramidal structure of authority in Amodu Tijani v. Secretary, Southern Nigeria.s There, Haldane described the "radical or final title of the Sovereign" as ultimately underlying all rights of the original inhabitants to possess land. The Head of the modern state owned "a pure legal estate," he stated. By inference, all other inhabitants possessed an impure legal title. More, the secondary scientized language of lawyers imposed a right of private property onto the indigenous peoples even though many Amerindian tribes, especially the nomadic tribes of the Western plains and of the Aretic Inuit, shared property as a communal heritage. Indeed, to the extent that 'property' involved an exclusivity of possession, it was even difficult to describe Amerindians as sharing communal property.

Finally, the master discourse of a modern European state has privileged a patriarchal view of authority. This patriarchal view, I have suggested, contrasts with the bodily experienced customs of the early Amerindian tribes. Legal authority in the modern state emanates from a supreme pater who is believed to transcend the particular experiences of each individual citizen. The aboriginals could only sell their property to the patriarchal Head of the modem state; once property was sold, the Head had fiduciary duties toward the aboriginal peoples; this fiduciary relationship took "the nature of a private law duty." The patemalism was so overpowering that the Supreme Court held in $R$ v. Sparrow, for example, that the Head of the authoritative structure did not even have to gain the consent of aboriginal inhabitants in acting as a trustee.6 The Head could extinguish the right of aboriginals to fish in certain waters "in a manner 'necessarily inconsistent' with the continued enjoyment of aboriginal rights." And how could the Head do so? Through legislative enactments which the Head - by this time, the Parliament had enacted as "a complete Code". Of course, in contrast with the unwritten customs of many aboriginal tribes, the "complete Code" was written. All that mattered was that "the Sovereign's intention be clear and plain." And that requirement would be met, according to the Sparrow Court, if the Head were able to justify its extinguishment of an aboriginal claim in terms of a "valid objective" of the modem state. One such "valid objective", of course, was the prevention of harm to the indigenous population. To prevent harm to the indigenous populace constituted a "valid objective" which the expert knowers of the master discourse, not the indigenous clans and tribes, considered "compelling and substantial". Such justifications, made in the name of the indigenous inhabitants but through the imperative sense of authority of a modem state, "are not to undermine Parliament's ability and responsibility with respect to the creating and administering overall conservation and management plans." Parliament's goals must remain supreme in 'fact' as well as in legal theory. The assimilationist project of modem legal discourse is complete. The experiential, unwritten, gestural sense of authority of Amerindians has been swept into the language familiar to the expert knowers of the master discourse. The cognitive objects of the expert knowers have disembodied the lived practices of the indigenous inhabitants subuy, un-selfconsciously, and in ignorance of a bodily sense of legal authority.

Even the efforts of well-intentioned scholars and constitutional reformers have worked to conceal the formerly lived sense of authority shared amongst many indigenous Amerindian tribes. For one, the Royal Commission on Aboriginal Peoples in Canada has associated legal authority with a singular "source" - its term - or arche or final grounding. (Royal Commission, 1992, pp. 16-32) The Report of the Commissioners even italicizes the word "source" for emphasis. Legal rights are said to inhere in the "origins" of authority. In the view of the Commissioners, the "source" or "origins" of authority rests with the aboriginai peoples as juridically defined persons. Although the Royal Commission defers to the aboriginal peoples as the "inherent source" for their own rights, the nomenclature which the Royal Commission adopts takes for granted the sense of authority which privileges the cognate over the gestural, the written over the unwritten, and a rationality over the experiential. More, the Royal Commissio pictures the authority of the laws of aboriginal peoples in the terms of a pyramidal hierarchy of a modem state. The aboriginal peoples are to have "govern ments" which "co-exist" "under the Constitution [of course, written] witt. Federal and Provincial governments." The Royal Commission analyzes "the inherent source" of indigenous laws in terms of such a pyramidal hierarchy ol authority. Even the "right of self-government" is situated at the pinnacle of $\varepsilon$ series of vertically hierarchized "sources" of law. Finally, the Report once agair leaves it to the Head of the modem state to "circumscribe" the supreme principle of the indigenous peoples (that is, the "inherent right of self-government"). The aboriginal governments will be "sovereign" "within a certain constitutiona' sphere." And the expert knowers of the term, "inherent right of self-government will be expected to situate the term within the language of the secondary master genre: "it is essential that any new provision be justiciable as soon as it is passed." The courts will recognize such a justiciable right once the right is situ ated in the basic text called "the Constitution", it is believed. The Royia Commission carries through with the earlier European sense of a sovereigr authority even though one is hard ptessed to uncover such a concept of sover eignty in the historical tecords of the indigenous inhabitants of the present-duj Canada. The unwritten, bodily, authorless and experiential sense of law amongs Amerindians did not presuppose an ultimate "source" or "foundation" to thei laws. The sense of law of the Amerindians did not associate legal authority witt a source or foundation.

During the fall of 1992, the Federal and ten Provincial Governments called fo: the final victory of the authority of the modern European state. The Minister asked that the Canadian public approve a series of amendments to the basic con stitutional text in a national referendum. The Canadian electorate eventuall! defeated the amendments, known as the 1992 Charlottetown Agreement. In thy spirit of the Royal Commission on Aboriginal Peoples, the text of the Agreemen 
redefined the tribal members as "Aboriginal Peoples". The text also provided in section 41 that "the Constitution should be amended to recognize that the Aboriginal peoples of Canada have the inherent right of self-govemment within Canada." The newly constructed, singular juridical person, "Aboriginal Persons", was recognized as possessing the right of self-determination. More, the expert knowers of the master discourse alone were granted the authority to interpret such an "inherent right". More, in the spirit of the modern sense of authority, the aboriginal peoples were recognized as being organized into governments with patriarchal heads. The aboriginal governments were to be recognized as "one of three orders of government in Canada." Section 47 of the Charlottetown Agreement then re-situated the "inherent right of self-government" into a subordinate position vis-a-vis the federal legislature as a source of law:

A law passed by a government of Aboriginal peoples, or an assertion of its authority based on the inherent right provision may not be inconsistent with those laws which are essential to the preservation of peace, order and good government in Canada.

The term "peace, order and good government" was not a new one. Expert "knowers' have interpreted the phrase, "peace, order and good government", for over one hundred and fifty years through a series of widely divergent legal tests. ${ }^{7}$ The dominant constitutional discourse of the modern state has transformed and displaced the unwritten, bodily, experiential, authorless sense of legal authority into the constitutional doctrines of a modern state.

\section{Conclusion}

Order in thought. Violence by thought. The en-force-ment of violent thought in a modern state. The assimilation of the lived laws of the clan into the cognitive objects of the juridical surrogates of the modern state. At issue are two radically clashing senses of 'what is legal authority?'. The King's legal order leaves it to a transcendent Source to save that order. The King is dead. God save the King.

\section{Notes}

1. World Bank Report as quoted in Toronto Globe and Mail, Monday, 14 August (1995):Al0.

2. Guerin v. The Queen [1984] 2 S.C.R. 335, 13 D.L.R. (4th) 321 (S.C.C.).

3. (1832), 8 Wheaton 543,21 U.S. 240.

4. (1988), 14 App. Cas, 46 (P.C.).

5. [1921] 2 A.C. 399 (P.C.).

6. R. v. Sparrow [1990] I S.C.R. 1075, 70 D.L.R. (4th) 385.

7. A similar provision was also included in the Joint Parliamentary Committee Report issued on March 2nd, 1992. The latter provided that the Constitution should "guarantee" "the fundamental right of the aboriginal peoples to self-government."

\section{Bibliography}

ANDREWEs, A. (1962), "The Growth of the City-Stale'. pp. 15-55, in: H. LLoYd-JONES ed.., The Greeks. London: A.C.Watts.

Anscompe, Elizabeth (1978), 'On the Source of the Authority of the Stale', Ratio 10: 1-28.

ARENDT, Hannah (1961), 'What is Authority?', pp. 91-141, Berween Past and Future: Six Exercises in Political Thoughi. New York: Meridan.

ARTHUR, Marylin (1987), 'From Medusa to Cleopatra: Women in the Ancient World', pp. 79. 105, in: Renate BrIDenthal, Claudia KoONz eds., Becoming Visible: Women in European History. Boston: Houghton Miflin.

- (1973), 'Early Greece: The Origins of the Westem Attilude Toward Wornen'. Arethusa 6 (1): 7-58.

Balley, Alfred Goldsworthy ( 1969 2nd ed.), The Conflict of European and Eastem Algonkian Cultures, 1504-1700; A Study in Canadian Civilization. Toronio: University of Toronto Press,

BURNET, John (1896-97), 'Law and Nature in Greek Ethics', Intemational J. of Ethics, 7 (3): 328-33.

Conkurn, William (forthcoming), The Divine Origins of Legal Positivism. Dordrecht: Kluwer

- (1992, 1993). 'The End of Judicinl Review", Currens Legal Theory reprinted with revisions in Bert van Roermund, ed., Constitutional Review verfassungsgerichisbarkeit, Conssirusionele Toetsing. Pp. 33-54. Zwolle: Kluwer Law and Taxation Publishers.

- (1997), "Hegel, the Author and Authority in Sophocles" Antigone', pp. 122-59, in: Leslie RuBis, ed., Justice v. Law in Greek Political Thought. New York: Rowman \& Litulfield.

- (1996), 'The Invisible Author of Legal Authority', Law and Critique 7 (2): 173-92.

- (1998), The Phenomenology of Modem Legal Discourse: The Juridical Producrion and the Disclosure of Suffering. Aldershot/Brookfield USA/ Singapore/ Sydney: Darumouth/ Ashgate.

Canada, Royal Commission on Aboriginal Peoples

- (1992), Report vol. 2, Restrucsuring the Relationship. Otlawa: Queen's Printer.

- (1992). The Right of Aboriginal Self-Government and the Constisution: A Commentary. Ottuwa: Queen's Printer.

CoRnford, F.M. (1957), From Religion to Philosophy: A Study in the Origins of Westem Speculation. New York: Harper \& Sons.

DERRIDA, Jacques (1990), "Force of Law: The "Mystical Foundation of Authority"', Cardozo Law Review. Translated by Mary Quaintance, 11: 919-1045.

- (1994), Specters of Marx: The Stase of the Debt, the Work of Mourning, and the New International. Translated by Peggy Kamuf; introduction by Bernd Magnus \& Stephen Cullenberg. New York/London: Routledge.

DworkIN, Ronald (1986), Low's Empire. Cambridge, Mass, : Harvard University Press.

Foucsult, Michel (1991), 'Governmentality', pp. 87-104, in: Graham BuRCHeL1., Colin Gordon \& Peter Miller, eds., The Foucault Effecr: Studies in Governmenfalify. Chicago. University of Chicago Press.

- (1980). 'Two Lectures', pP. 91-97, in: Power/Knowledge: Selected Interviews \& Other Writings, 1972-1977, Colin Gordon ed. New York: Pantheon.

Franc15, R. Douglas; JonES, Richard; \& SMTrH, Donald B. (1988), Origins: Canadian Histon to Confederation. Toronto: Holt, Rinehart \& Winston: 1-17 and 58-75.

FranC1s, R. Douglas and SMITH, Donald B. (1990, 3rd edn), Readings in Canadian History. Pre-Confederation. Toronto. University of Toronto Press.

Frankfort, H., Frankfort, H.A., Wilson, John A., Jacobsen, Thorkild (1949), Before Philosophy: The Intellecrual Adventure of Ancient Man. Harmondsworth: Penguin.

Guson, Étienne (1941), God and Philosophy. New Havent: Yale University Press.

Hart, H.L.A. (1994, 2nd edn.). The Concept of Law. Postscript edited by Penelope A. Bulloch 
\& Joseph Raz. Oxford: Clarendon Press.

Hriarts, Bernard J. (1992), "Coming to our Senses": Communication and Legal Expression in Performance Cultures', Emory Low Journal 4l (4): 875-960.

Kelsex, Hans (1986), 'The Function of a Constitution', pp. 109-22, in: Essays on Kelsen. Oxford: Clarendon Press.

- (1970), The Pure Theory of Law. Translated by Max Knight. Berkeley. University of Califomia Press.

KRIEGER, Leonard (1968, 1973), 'Authority', pp. 141-62, in: Philip P. Weiner, Dictionary of

$\therefore$ the History of ldeas: Studies of Selected Pivotal Ideas, vol. 1. New York: Charles Scribner's Sons.

LEVINAS, Emmanuel (1969), Totality and Infinity. Translated by Alphonso Lingis. Pittsburgh: Duquenes University Press.

LLoYd-Jones, Hugh (1983, 2nd ed.), The Justice of Zeus. Berkeley, Los Angeles, London: University of Califomia Press.

MARTIN, Calvin (1991), 'The European Impact on the Culture of a Northeastem Algonquian Tribe: An Ecological Interpretation', pp. 185-211, in: Michael S. Cross \& Gregory S. KEALEY, eds., Economy and Society During the French Regime, to 1759: Readings in Canadian Social History. Toronto: McClelland \& Stewart.

Rousseau, Jacques and Brown, George W. (1990), 'The Indians of Northeastern North America', pp. 3-16, in: R. Douglas Francls \& Donald B. SMmr, ed., Readings in Canadian History: Pre-Confederation. Toronto: Holt, Rinehart, \& Winston.

SopHocles (1962), Sophocles: Plays and Fragments. Pt 3: Antigone. Translated by Richard C. JeBB. Amsterdam: Servio Publishers. Also translated (1984 a) by Robert FAGIss in The Three Theban Plays: Antigone, Oedipus the King, and Oedipus at Colonus. New York \& Harmondsworth: Penguin. Also translated (1984 b) by David Grean in Sophocles $I$. Chicago: University of Chicago Press; Phoenix Books.

THOMson, George (1954), Srudies in Ancient Greek Society: the Prehistoric Aegeant. London: Lawrence \& Wishart.

TuRPEL, Mary Ellen (1991), 'Aboriginal Peoples and the Canadian Charter. Interpretive Monopolies and Cultural Differences', pp. 503-29, in: Patrick DeviN, ed., Canadian Perspectives on Legal Theory. Toronto: Emond-Montgomery.

TragerR, Bruce G. (1969), The Huron: Farmers of the North. New York: Holth Rinehart and Winston: 68-82, 121-26.

-(1985), Narives and Newcomers: Canada's "Heroic Age" Reconsidered. Kingston/Montreal: McGill-Queens.

- (1990), 'The French Presence in Huronia: The Structure of Franco-Huron Relations in the First Half of the Seventeenth Century', pp. 16-42, in: R. Douglas Francis \& Donald B. SMrrt ed, Readings in Caradian History: Pre-Confederation. Toronto: Holt, Rinehart, \& Winston.

VeRNANT, Jean-Pierre (1974), Myth and Society in Ancient Greece. Translated by Janet LLOYD. Sussex: Harvester.

-(1982), The Origins of Greek Thought. Ithaca: Comell University Press.

Young, William C. (1994). "The Body Tamed: Tying and Tatooing among the Rashanyda Bedouin', pp. 58-75, in: Nicole Sault, ed., Many Mirrors: Body Image and Social Relations. Edited by Nicole Sault; foreword by Peggy Reeves SANDRY. New Brunswick, New Jersey: Rulgers University Press.

Z17EK, Slavoj (1991). For they know not what they do: Enjoyment as a political factor. New York: Verso.

-(1989), The Sublime Object of Ideology. New York: Verso.

- (1993), Tarrying with the Negative: Kant, Hegel and the Critique of Ideology. Durham: Duke University Press. 